M. Ye. Blazheyevskiy, N. Yu. Bondarenko, Yu. Yu. Serdiukova, V. D. Yaremenko

National University of Pharmacy, Ukraine

\title{
Determination of L-Cystine in Tablets Using the Chemiluminescence Method
}

Aim. To develop the method for the quantitative determination of $L$-cystine in sublingual tablets Elthacin ${ }^{\circledR}$ using the method of chemiluminescence inhibition in the $\mathrm{H}_{2} \mathrm{~L}$ (luminol) $-\mathrm{H}_{2} \mathrm{O}_{2}-\mathrm{Hb}$ (hemoglobin) system.

Materials and methods. The study objects were the pure substance of $L$-cystine of pharmaceutical grade and sublingual tablets Elthacin ${ }^{\circledR}$ produced by the Medical Scientific-Production Complex "Biotics Ltd" (Russia) containing $70 \mathrm{mg}$ of glycine, $L$-glutaminic acid and $L$-cystine in their composition. The intensity of chemiluminescence was measured on the device with a FEU-84-A photoelectric multiplier using an IMT-0.5 measuring instrument of low currents and a quick-acting automatic potentiometer.

Results and discussion. The method of the $L$-cystine quantitative determination in tablets based on the inhibition of chemiluminescence in the $\mathrm{H}_{2} \mathrm{~L}-\mathrm{H}_{2} \mathrm{O}_{2}-\mathrm{Hb}$ system has been developed. The calibration graph was linear over the concentration range from 7 to $70 \mu \mathrm{g} \cdot \mathrm{mL}^{-1}$. No interferences were observed in the presence of common components of the tablets, such as glycine and $L$-glutaminic acid. RSD $= \pm 2.35 \%,(\delta=+1.13 \%), \operatorname{LOD}(3 S)=4 \mu \mathrm{g} \cdot \mathrm{mL}^{-1}, \mathrm{LOQ}(10 S)=13 \mu \mathrm{g} \cdot \mathrm{mL}^{-1}$ for the sublingual tablets Elthacin ${ }^{\circledR}$.

Conclusions. The method proposed is promising for further research on the subject of its application for the determination of $L$-cystine in drugs.

Key words: L-cystine; inhibition; luminol; chemilumeniscence; hemoglobin

М. Є. Блажеєвський, Н. Ю. Бондаренко, Ю. Ю. Сердюкова, В. Д. Яременко

Національний фрармацевтичний університет, Україна

Визначення $L$-цистину в пігулках 3 використанням методу хемілюмінесценції

Мета. Метою даної роботи було розроблення методики кількісного визначення $L$-цистину в сублінгвальних таблетках Елтацин ${ }^{\circledR}$ за ефектом інгібування хемілюмінесценції системи $H_{2} L$ (люмінол) $-H_{2} \mathrm{O}_{2}-H_{b}$ (гемоглобін).

Матеріали та методи. Об’єктом дослідження були пігулки під'язикові Елтацин ${ }^{\circledR}$ виробництва ТОВ Медичний науково-виробничий комплекс «Биотики» (Росія) складу: гліцину, кислоти L-глутамінової та $L$-цистину по 70 мг та субстанція $L$-цистину. Інтенсивність хемілюмінесценції вимірювали на установці з фотоелектронним помножувачем ФЭУ-84-А, вимірювачем малих струмів ИМТ-0,5 і швидкодіючим потенціометром-самописцем.

Результати та їх обговорення. Опрацьована методика та показана можливість кількісного визначення $L$-цистину в пігулках під'язикових Елтацин ${ }^{\circledR}$ по 70 мг методом інгібування хемілюмінесценції системи $\mathrm{H}_{2} L-\mathrm{H}_{2} \mathrm{O}_{2}-H b$. Калібрувальний графік лінійний в діапазоні концентрацій від 7 до 70 мкг · мл ${ }^{-1}$. Присутність гліцину та $L$-глутамінової кислоти не чинила жодного впливу на інтенсивність хемілюмінесценції. RSD = $\pm 2,35 \%$, $(\delta=+1,13 \%)$, LOD (3S) = 4 мкг $\cdot$ мл $^{-1}, \mathrm{LOQ}(10 S)=13$ мкг $\cdot$ мл $^{-1}$ для сублінгвальних таблеток Елтацин ${ }^{\circledR}$.

Висновки. Запропонований метод може бути використаний для визначення L-цистину у лікарських препаратах.

Ключові слова: L-цистин; інгібування; люмінол; хемілюмінесценція; гемоглобін

Н. Е. Блажеевский, Н. Ю. Бондаренко, Ю. Ю. Сердюкова, В. Д. Яременко

Национальный фармацевтический университет, Украина

Определение $L$-цистина в таблетках с использованием метода хемилюминесценции

Цель. Целью данной работи была разработка методики количественного определения L-цистина в сублингвальных таблетках Элтацин ${ }^{\circledR}$ по эфрфекту ингибирования хемилюминесценции системы $H_{2} L$ (люминол) $-H_{2} \mathrm{O}_{2}-H_{b}$ (гемоглобин).

Материалы и методы. Объектом исследования были сублингвальные таблетки Элтацин ${ }^{\circledR}$ производства ООО Медицинский научно-производственный комплекс «Биотики» (Россия) состава: глицина, кислоты $L$-глутаминовой и L-цистина по 70 мг и субстанция L-цистина. Интенсивность хемилюминесценции измеряли на установке с фотоэлектронным умножителем ФЭУ-84-А, измерителем малых токов ИМТ-0,5 и быстродействующим потенциометром-самописцем.

Результаты и их обсуждение. Разработана методика и показана возможность количественного определения $L$-цистина в сублингвальных таблетках Элтацин ${ }^{\circledR}$ по 70 мг методом ингибирования хемилюминесценции системы $\mathrm{H}_{2} \mathrm{~L}-\mathrm{H}_{2} \mathrm{O}_{2}-\mathrm{Hb}$. Калибровочный график линеен в диапазоне концентраций от 7 до 70 мкг · мл ${ }^{-1}$. Присутствие глицина и $L$-глутаминовой кислоты не оказывало никакого влияния на интенсивность хемилюминесценции. RSD = $\pm 2,35 \%$,

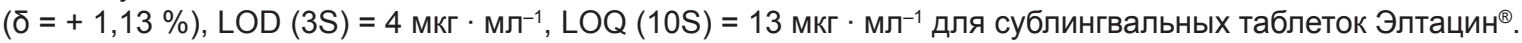

Выводы. Предложенный метод может быть использован для определения L-цистина в препаратах.

Ключевые слова: L-цистин; ингибирование; люминол; хемилюминесценция; гемоглобин 
Introduction. $L$-Cystine (3,3'-dithio-bis-2-aminopropionic acid, dicystein) is one of the well-known substituted of $\alpha$-aminoacids, a stable (oxidized) form of the aminoacid of cysteine. It participates in the formation of peptides and other proteins during the formation of their structure. $L$-cystine provides elasticity of keratin; therefore, it is a part of complexes of vitamins for improvement of appearance of the skin and hair, biologically active additives and shampoos.

A wide range of medicinal products based on $L$-cystine can be used in cases of intoxication with heavy metals, as well as antioxidants, hepatoprotectors, detoxicants, immunomodulators, mucolytics, etc. Often $L$-cystine is also used as part of the complex therapy for the treatment of diabetes, Alzheimer's disease, bronchitis, as well as rehabilitation after surgery and joint diseases.

The drug is available in the form of capsules and ampoules, and is also a part of the combined medications, such as the tablets Elthacin ${ }^{\circledR}$ (the main composition: $L$-cystine, $70 \mathrm{mg}$; glycine, $70 \mathrm{mg}$; $L$-glutaminic acid, fillers: methylcellulose, $7.8 \mathrm{mg}$; magnesium stearate, $2.2 \mathrm{mg}$ ).

Several methods, such as those based on iodometric titration using diperoxyadipic acid, voltamperometry, polarography, capillary electrophoresis method, flow-injection analysis after its reduction to cysteine with the subsequent spectrophotometric detection, thin-layer chromatography, liquid chromatography in combination with massspectrometry and also using Raman microscopy combined chemometrics of the PCA (Principal Component Analysis) and HCA (Hierarchical Cluster Analysis) have been reported for its determination within different ranges of concentrations [1-9].

The advantages of the iodometric determination using diperoxy acid as a reagent are selectivity: other amino acids being the constituents of the combined dosage forms and excipients do not interfere the $L$-cystine determination, but there is a need for the synthesis of the analytical reagent [1]. All these methods require specialized equipment and expertise and can be laborious for the routine analysis. The European Pharmacopoeia (EPh 8.0) recommends the method of inverse bromatometry for the quantitative determination of $L$-cystine. The sensitivity of the recommended method is limited by the relatively high concentration of the titrant $\left(0.1 \mathrm{~mol} \cdot \mathrm{L}^{-1}\right)$ $[10,11]$.

The aim of our work was to develop a selective, sufficiently sensitive and easy-to-perform procedure for the routine analysis of $L$-cystine in the drug Elthacin ${ }^{\circledR}$.

Materials and methods. The study objects were the pure substance of $L$-cystine of pharmaceutical grade (the content of the main substance was $98.5 \%$ ) and sublingual tablets Elthacin ${ }^{\circledR}$ produced by the Medical ScientificProduction Complex "Biotics Ltd" (Russia) containing $70 \mathrm{mg}$ of glycine, $L$-glutaminic acid and $L$-cystine in their composition [10].

Solutions were prepared by the volume-weight method at 293 K. Double distilled water (DDW) was used to prepare the solutions in all cases.

Standard $1 \cdot 10^{-3} \mathrm{~mol} \cdot \mathrm{L}^{-1}$ solution of Luminol (5-amino-2.3-dihydro-1.4-ftalazindion, $H_{2} L$, RPF Synbias,
Ukraine) was used. $0.1772 \mathrm{~g}$ of 3-Aminophthalhydrazide with qualification " $R$ " was transferred in a $100 \mathrm{~mL}$ volumetric flask, dissolved in $10 \mathrm{~mL}$ of $0.01 \mathrm{~mol} \cdot \mathrm{L}^{-1}$ sodium hydroxide solution and diluted to the volume with DDW. The solution was kept in a dark place.

$0.1 \mathrm{~mol} \cdot \mathrm{L}^{-1}$ solution of sodium hydroxide was used for the medium $\mathrm{pH}$ stabilization, the solution $\mathrm{pH}$ was controlled by an Ionomer I-130 laboratory potentiometer with an ESL-43-07 glass electrode and silver-chloride electrode and a laboratory Ionomer I-130 (ZIP, Gomel, Belarus).

Hydrogen peroxide $\left(\mathrm{H}_{2} \mathrm{O}_{2}\right) 5.8 \%$ (wt.) solution was prepared from $58 \%$ high pure preparation (produced by LTD Inter-Syntes, Boryslav, Ukraine) by its 10 time dilution with DDW: $10 \mathrm{~mL}$ was transferred into a $100 \mathrm{~mL}$ volumetric flask and diluted to the volume at $293 \mathrm{~K}$. This solution was stored at reduced temperature of $+8-10^{\circ} \mathrm{C}$. The content of hydrogen peroxide in solution was controlled by permanganatometric titration.

The working solution of $\mathrm{H}_{2} \mathrm{O}_{2} 0.058 \%$ (wt.) $\left(1.7 \cdot 10^{-2} \mathrm{~mol} \cdot \mathrm{L}^{-1}\right)$ was obtained by the appropriate dilution of the original solution exactly 100 times. The working solution can be used throughout the day.

Human blood hemoglobin $(H b)$ produced by Simko Ltd, Lviv, Ukraine was used as a catalyst. Hemoglobin solution $100 \mu \mathrm{g} \cdot \mathrm{mL}^{-1}$ was prepared by dissolving in a $100 \mathrm{~mL}$ volumetric flask of $10 \mathrm{mg}$ hemoglobin in $50 \mathrm{~mL}$ DDW by heating to $313 \ldots 323 \mathrm{~K}$ and adding $1 \mathrm{~mL}$ of $1.0 \mathrm{~mol} \cdot \mathrm{L}^{-1}$ sodium hydroxide solution. It was diluted to the volume with DDW at $293 \mathrm{~K}$ and stirred. The working solution of hemoglobin was prepared by dilution with DDW of the initial one exactly 100 times. The working solution can be used throughout the day.

The intensity of chemiluminescence was measured in relative units on the device with a FEU-84-A photoelectric multiplier using an IMT-0.5 measuring instrument of low currents and a quick-acting (time constant $0.1 \mathrm{~s}$ ) automatic potentiometer. The reaction accompanying CL was performed in a cylindrical quartz cell of $30 \mathrm{~mm}$ in diameter with the working volume of $10 \mathrm{~mL}$. The following order of mixing reagents was performed: to the mixture of luminol indicator in the alkali solution and $\mathrm{H}_{2} \mathrm{O}_{2}$, with the presence or absence of $L$-cystine solution in the control experiment, $0.50 \mathrm{~mL}$ of $\mathrm{Hb}$ was added with the help of a dosage pipette $\mathrm{P}-1$, and the kinetic curve of chemiluminescence intensity $(I)$ in relative units $(I)$ - time (s) was registered. The dosage pipette is built in to the mobile keeper that isolates photocathode of a photoelectric multiplier from outside light, and further allows working at the common lighting. All experiments were performed at $293 \mathrm{~K}$.

For the optimal conditions for the chemiluminescence occurrence in the $\mathrm{H}_{2} \mathrm{~L}-\mathrm{H}_{2} \mathrm{O}_{2}-\mathrm{Hb}$ analytical system the conditions determined earlier as a result of detailed studies by one of the authors were used. They are given in the monograph [12].

For the analytical signal, the value $\Delta I$ (rel. un.) was chosen. It is the difference between the maximum values of the CL intensities in the control (in the absence of an inhibitor) and working experiments. 
In the course of studies, it was found that under the optimum conditions $\left(c(\mathrm{NaOH})=0.05 \mathrm{~mol} \cdot \mathrm{L}^{-1}\right.$, $c\left(\mathrm{H}_{2} \mathrm{O}_{2}\right)=8.53 \cdot 10^{-4} \mathrm{~mol} \cdot \mathrm{L}^{-1}, c\left(H_{2} L\right)=10^{-4} \mathrm{~mol} \cdot \mathrm{L}^{-1}$, $\left.C(H b)=5 \cdot 10^{-2} \mu \mathrm{g} \cdot \mathrm{mL}^{-1}\right) L$-cystine exhibited the inhibitory effect on the intensity of the CL in $\mathrm{H}_{2} \mathrm{~L}-\mathrm{H}_{2} \mathrm{O}_{2}-$ $\mathrm{Hb}$ system [12]. This phenomenon was used by us to develop a new method for the quantitative determination of $L$-cystine in solutions of tablets Elthacin ${ }^{\circledR}$.

The standard solution sample (SSS) of $L$-cystine $0.7 \mu \mathrm{g} \cdot \mathrm{mL}^{-1}$ was prepared as follows: $0.0710 \mathrm{~g}$ of $L-$ cystine was transferred in a $100 \mathrm{~mL}$ volumetric flask and dissolved in $10 \mathrm{~mL}$ of $1 \mathrm{~mol} \cdot \mathrm{L}^{-1}$ of sodium hydroxide solution and diluted to the volume with DDW. The working solution of $L$-cystine was obtained by the appropriate dilution of the original solution in the required number of times for analysis.

Procedure of determination. Solutions were added to a chemiluminescent quartz cell consistently as follows: $0.50 \mathrm{~mL}$ of $1 \cdot 10^{-3} \mathrm{~mol} \cdot \mathrm{L}^{-1} H_{2} L, 0.50 \mathrm{~mL}$ of $1 \mathrm{~mol} \cdot \mathrm{L}^{-1}$ sodium hydroxide solution, $(10-\mathrm{x}) \mathrm{mL}$ of DDW where $\mathrm{x}$ was the total volume of all reagents and samples, $(\mathrm{mL}), 0.50 \mathrm{~mL}$ of $1.7 \cdot 10^{-2} \mathrm{~mol} \cdot \mathrm{L}^{-1} \mathrm{H}_{2} \mathrm{O}_{2}$ and $0.5 \mathrm{~mL}$ of a dilute working-standard solution of $L$-cystine. A cell with the mixture was placed in a chemiluminometer, and $0.5 \mathrm{~mL}$ of the working solution of hemoglobin with the concentration of $1 \mu \mathrm{g} \cdot \mathrm{mL}^{-1}$ was added.

Similarly, the control experiment with DDW instead of the use of dilute working-standard solution of $L$-cystine in the same amount was performed. The content of $L$-cystine was calculated by Equation 1 .

Procedure of the quantitative determination of L-cystine in tablets Elthacin ${ }^{\circledR}$. Approximately $0.22 \mathrm{~g}$ of powdered tablets (accurately weighed) was transferred into a $100 \mathrm{~mL}$ volumetric flask, dissolved in $10 \mathrm{~mL}$ of $1 \mathrm{~mol} \cdot \mathrm{L}^{-1}$ sodium hydroxide solution and diluted to the volume with DDW. Similarly, L-cystine SSS was prepared by the volume-weighted method with the concentration of $0.710 \mu \mathrm{g} \cdot \mathrm{mL}^{-1}$. L-cystine working solutions were prepared by the appropriate dilution immediately before the analysis.

When performing the experiment a certain order of adding solutions was observed in accordance with the above mentioned procedure.

The content of $L$-cystine in $X$ ( $\mathrm{g}$ to one tablet) was calculated by the Equation:

$$
X=\frac{m_{s t} \times(\Delta I) \times \bar{m} \times w}{\left(\Delta I_{s t}\right) \times m_{n} \times 100 \%},
$$

where: $m_{s t}-$ is the weight of $L$-cystine in SSS, $g ;(\Delta l)-$ is the maximum value of $\Delta I$ in the working experiment, relative units; $\left(\Delta I_{s t}\right)$ - is the maximum value of $\Delta I_{s t}$ in SSS, relative units; $\bar{m}$ - is the average tablet weight $(n=20)$, g; $m_{n}-$ is the mass of pounded tablets in the batches used for analysis, g; $w$ - is the content of the basic substance in the standard sample, $\%$.

Results and discussion. The presence of $L$-cystine in the $\mathrm{H}_{2} \mathrm{~L}-\mathrm{H}_{2} \mathrm{O}_{2}-\mathrm{Hb}$ system leads to a decrease in the maximum intensity of $\mathrm{CL}$, indicating inhibition of the CL reaction. This effect increases with increasing of the inhibitor of the process concentration (Fig. 1).

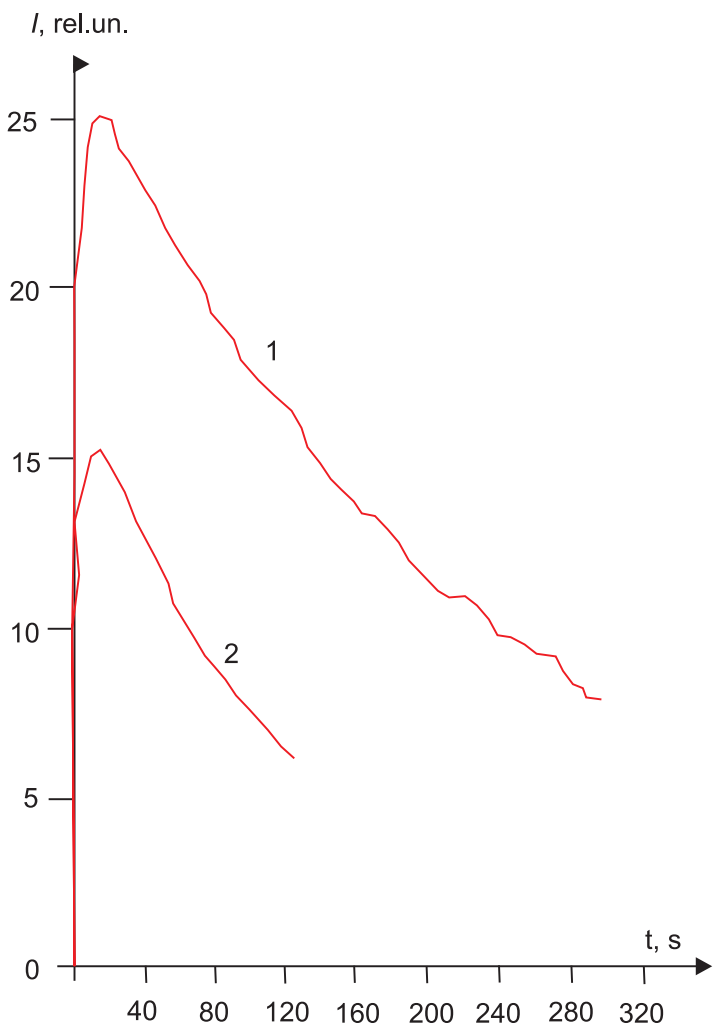

Fig. 1. Kinetic chemiluminescent curves in the system: $1-\mathrm{H}_{2} \mathrm{~L}-\mathrm{H}_{2} \mathrm{O}_{2}-\mathrm{Hb}$ (in the absence of $\mathrm{L}$-cystine), $2-\mathrm{H}_{2} \mathrm{~L}-\mathrm{H}_{2} \mathrm{O}_{2}-\mathrm{Hb}-\mathrm{L}$-cystine. $\mathrm{c}(\mathrm{NaOH})=0.05 \mathrm{~mol} \cdot \mathrm{L}^{-1}$ $c\left(\mathrm{H}_{2} \mathrm{O}_{2}\right)=8.5 \cdot 10^{-4} \mathrm{~mol} \cdot \mathrm{L}^{-1}, c\left(\mathrm{H}_{2} \mathrm{~L}\right)=1 \cdot 10^{-4} \mathrm{~mol} \cdot \mathrm{L}^{-1}$, $C(H b)=5 \cdot 10^{-2} \mu \mathrm{g} \cdot \mathrm{mL}^{-1}, C(L$-cystine $)=35 \mu \mathrm{gL}^{-1}$

The difference between the maximum values of the $\mathrm{CL}$ intensities in the control (in the absence of the inhibitor) and the working experiments $\Delta I$ (rel. un.) was chosen as the analytical signal.

It was found that the dependence of $\Delta I$ on the concentration of $L$-cystine was linear in the concentration range from 7 to $70 \mu \mathrm{g} \cdot \mathrm{mL}^{-1}$ (Fig. 2).

The linear equation is $\Delta I=(0.24 \pm 0.01) \cdot C, r=0.999$, $n=5$ where $C$ is the concentration of $L$-cystine solution, $\mu \mathrm{g} \cdot \mathrm{mL}^{-1}, \operatorname{LOD}(3 \mathrm{~S})=4 \mu \mathrm{g} \cdot \mathrm{mL}^{-1}$, LOQ $(10 \mathrm{~S})=$ $13 \mu \mathrm{g} \cdot \mathrm{mL}^{-1}$.

To determine the possibility of using the method developed for the quantitative determination of the API $L$-cystine in a dosage form containing a number of co-components and excipients the method of additives was used.

The amount of additives was chosen so that the difference in maximum CL intensities was statistically significant - the condition of application of the additive method, and the total concentration of $L$-cystine in the test solutions was within the accuracy of their determination (calibration graph). The linear dependence, which allowed determining the content of $L$-cystine is presented in Fig. 3. It should be noted that the slope of the line obtained within the error of the experiment coincided well with that of the calibration graph.

For intermediate precision three different concentrations of $L$-cystine (in the linear range) were analyzed by the standard addition method proposed in the same day and the second consecutive day (inter-day precision). The means RSD and accuracy results intra and interday studies are given in Tab. 1. The data obtained indi- 


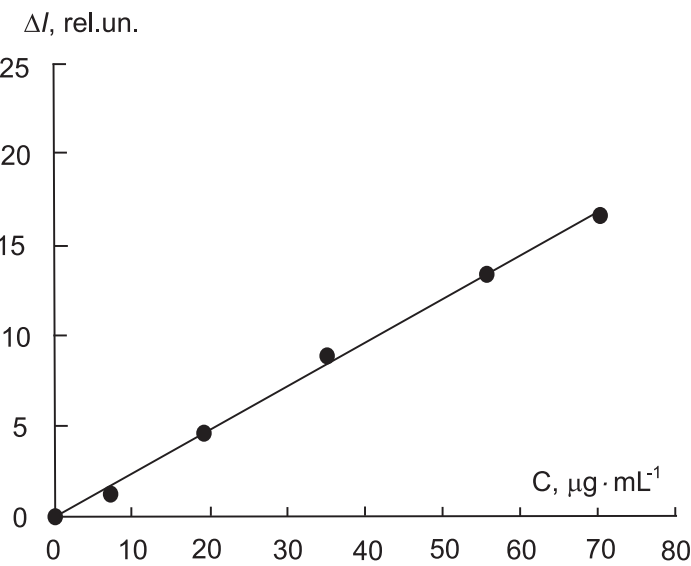

Fig. 2. Dependence of $\Delta /$ on the concentration of $L$-cystine in the chemiluminescence system $\mathrm{H}_{2} \mathrm{~L}-\mathrm{H}_{2} \mathrm{O}_{2}-\mathrm{Hb}$. $c(\mathrm{NaOH})=0.05 \mathrm{~mol} \cdot \mathrm{L}^{-1}, c\left(\mathrm{H}_{2} \mathrm{O}_{2}\right)=8.5 \cdot 10^{-4} \mathrm{~mol} \cdot \mathrm{L}^{-1}$ $c\left(H_{2} L\right)=1 \cdot 10^{-4} \mathrm{~mol} \cdot \mathrm{L}^{-1}, C(H b)=5 \cdot 10^{-2} \mu \mathrm{g} \cdot \mathrm{mL}^{-1}$

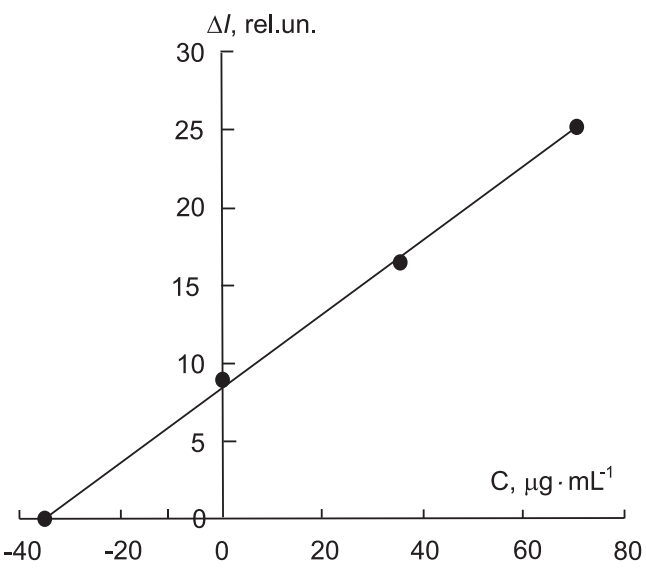

Fig. 3. The dependence of $\Delta /$ on the concentration of $L$-cystine in the solution of the drug Elthacin and solutions of the drug with various additives of $L$-cystine (the method of standard additions)

Table 1

Intra-day and inter-day precision and accuracy data of $L$-cystine $(n=7, \mathrm{P}=0.95)$

\begin{tabular}{|c|c|c|c|c|c|c|c|}
\hline & & \multicolumn{3}{|c|}{ Intra-day } & \multicolumn{3}{|c|}{ Inter-second day } \\
\hline & $\begin{array}{c}\text { Added (together) } \\
\left(\mu \mathrm{g} \cdot \mathrm{mL}^{-1}\right)\end{array}$ & $\begin{array}{c}\text { Found } \\
\left(\mu \mathrm{g} \cdot \mathrm{mL}^{-1}\right)\end{array}$ & $\begin{array}{c}\text { Precision** } \\
\text { RSD (\%) }\end{array}$ & $\begin{array}{c}\text { Accuracy }^{* * *} \\
(\text { Bias \%) }\end{array}$ & $\begin{array}{c}\text { Found* } \\
\left(\mu \mathrm{g} \cdot \mathrm{mL}^{-1}\right)\end{array}$ & $\begin{array}{c}\text { Precision** } \\
\text { RSD (\%) }\end{array}$ & $\begin{array}{c}\text { Accuracy*** } \\
\text { (Bias \%) }\end{array}$ \\
\hline \multirow{3}{*}{ L-cystine } & $+034.6^{*}$ & $34.5 \pm 0.8$ & 2.4 & -0.3 & $34.3 \pm 0.8$ & 2.4 & -0.9 \\
\hline & $+35.0(69.6)$ & $69.0 \pm 1.4$ & 2.1 & -0.9 & $69.2 \pm 1.3$ & 2.0 & -0.6 \\
\hline & $+70.0(104.6)$ & $104.2 \pm 1.9$ & 1.9 & -0.4 & $103.5 \pm 1.9$ & 1.9 & -0.7 \\
\hline
\end{tabular}

Note: ${ }^{*}$ Mean \pm Standard Error (Mean \pm Standard Deviation·Student coef. (t) $/ \sqrt{ } n$; ** - RSD: Relative Standard Deviation;

*** - Bias \%: [(Found - Added (together)/Added (together)] · 100.

The results of the $L$-cystine quantitative determination in sublingual tablets Elthacin ${ }^{\circledR}, 70 \mathrm{mg}$

\begin{tabular}{|l|c|c|}
\hline \multicolumn{1}{|c|}{ Contents of L-cystine, (mg per tab.) } & Found L-cystine, $\mathrm{mg}$ & Metrological characteristics \\
\hline & 68.40 & $\bar{X} \pm \Delta \bar{X}=69,98 \pm 2.05$ \\
L-cystine $70 \mathrm{mg}$ & 71.40 & $S= \pm 1.65$ \\
$*(a=69.2 \mathrm{mg})$ & 70.80 & $\mathrm{RSD}= \pm 2.35 \%$ \\
& 71.30 & $* * \delta=+1.13 \%$ \\
\hline
\end{tabular}

Note: ${ }^{*} a$ - the $L$-cystine content by the Certificate, $g ;{ }^{* *} \delta=(\bar{X}-a) 100 / a$.

cate the absence of a negative effect of excipients on the results of the determination of API in a dosage pharmaceutical form.

The results of these preliminary studies allowed us to perform the analysis of the tablets using a simpler standard method. These results of the quantitative determination of $L$-cystine in tablets Elthacin ${ }^{\circledR}, 70 \mathrm{mg}$ are given in Tab. 2.

The analysis of the data showed that the means relative standard deviation did not exceed the permissible value. Since $\delta \leq$ RSD, the results of the determination of $L$-cystine were considered to be correct (systematic er- ror is absent). The sensitivity for the $L$-cystine quantitative determination was calculated: $\mathrm{LOD}(3 \mathrm{~S})=4 \mu \mathrm{g} \cdot \mathrm{mL}^{-1}$, $\operatorname{LOQ}(10 \mathrm{~S})=13 \mu \mathrm{g} \cdot \mathrm{mL}^{-1}$.

Conclusions. The new method has been developed, and the possibility for the quantitative determination of $L$-cystine in sublingual tablets Elthacin ${ }^{\circledR}, 70 \mathrm{mg}$, using the method of chemiluminescence inhibition in the $\mathrm{H}_{2} \mathrm{~L}-$ $\mathrm{H}_{2} \mathrm{O}_{2}-\mathrm{Hb}$ system has been shown. $\mathrm{RSD}= \pm 2.35 \%$, $(\delta=+1.13 \%), \operatorname{LOD}(3 \mathrm{~S})=4 \mu \mathrm{g} \cdot \mathrm{mL}^{-1}$, LOQ $(10 \mathrm{~S})=$ $13 \mu \mathrm{g} \cdot \mathrm{mL}^{-1}$.

Conflict of interests: authors have no conflict of interests to declare. 


\section{REFERENCES}

1. Blazheyevskiy, M. Y. Iodometric determination of cysteine in pharmaceutical formulation using diperoxyadipinic acid as reagent / M. Y. Blazheyevskiy, V. P. Moroz // Methods and objects of chemical analysis. - 2018. - № 13 (1). - P. 13-17. https://doi.org/10.17721/ moca.2018.13-17

2. A New Route to the Electroanalytical Determination of Cystine / M. S. Damle, L. A. A. Newton, M. M. Villalba et al. // Electroanalysis. 2010. - № 22 (21). - P. 2491-2495. https://doi.org/10.1002/elan.201000198

3. Shukla, J. Analysis of cystine in human blood for monitoring of cases of burns / J. Shukla, K. S. Pitre // J. Pharm. and Biomed. Anal. 2002. - № 27 (5). - P. 821-826. https://doi.org/10.1016/s0731-7085(01)00486-1

4. Electrocatalytic oxidation and flow-injection determination of sulfur-containing amino acids at graphite electrodes modified with a ruthenium hexacyanoferrate film / L. G. Shaidarova, S. A. Ziganshina, L. N. Tikhonova, G. K. Budnikov // J. of Analytical Chem. 2003. - № 58 (12). - P. 1144-1150. https://doi.org/10.1023/b:janc.0000008953.67244.c2

5. Шпак, А. В. Определение аминокислот методом капиллярного электрофореза без предварительной дериватизации / А. В. Шпак, А. В. Пирогов, О. А. Шпигун // Журн. аналит. химии. - 2003. - Т. 58, № 7. - С. 317-319.

6. Ensafi, A. A. Flow injection spectrofluorimetric determination of cystine and cysteine / A. A. Ensafi, B. Rezaei, S. Nouroozi // J. Braz. Chem. Soc. - 2009. - № 20 (2). - P. 288-293. https://doi.org/10.1590/s0103-50532009000200013

7. Thin-layer chromatography of amino acids / S. A. Bhawani, M. N. Mohamad Ibrahim, O. Sulaiman et al. // J. Liq. Chrom. \& Rel. Tech. 2012. - № 35 (11). - P. 1497-1516. https://doi.org/10.1080/10826076.2011.619039

8. Quantification of cysteine in human renal proximal tubule cells using liquid chromatography - tandem mass spectrometry / A. Jamalpoor, R. W. Sparidans, C. P. Casellas et al. // Biomed. Chromatogr. - 2018. - № 32 (8). - P. 4238. https://doi.org/10.1002/bmc.4238

9. Detection of 1-Cysteine in wheat flour by Raman microspectroscopy combined chemometrics of HCA and PCA/ N. Cebi, C. E. Dogan, A. Develioglu et al. // Food Chem. - 2017. - № 228. - P. 116-124. https://doi.org/10.1016/j.foodchem.2017.01.132

10. Cystine / European Pharmacopoeia 9.0. - Strasbourg : Council of Europe, 2016. - P. 2187-2188.

11. Чернобровкин, М. Г. Определение аминокислот в препарате «Элтацин» / М. Г. Чернобровкин, Н. В. Кольцова, Б. Н. Шепелев // Фармация. - 2004. - № 5. - С. 18-20.

12. Blazheyevskiy, M. Y. Application of peroxy acids as disinfectants and sterilization agents (monograph) / M. Y. Blazheyevskiy, D. N. Riabko. - Saarbrücken (Deutschland) : LAP LAMBERT Academic Publishing, 2014.

\section{REFERENCES}

1. Blazheyevskiy, M. Y., \& Moroz, V. P. (2018). Iodometric determination of cystine in pharmaceutical formulation using diperoxyadipic acid as reagent. Methods and objects of chemical analysis, 13 (1), 13-17. https://doi.org/10.17721/moca.2018.13-17

2. Damle, M. S., Newton, L. A. A., Villalba, M. M., Leslie, R., \& Davis, J. (2010). Plumbagin: A New Route to the Electroanalytical Determination of Cystine. Electroanalysis, 22 (21), 2491-2495. https://doi.org/10.1002/elan.201000198

3. Shukla, J., \& Pitre, K. . (2002). Analysis of cystine in human blood for monitoring of cases of burns. Journal of Pharmaceutical and Biomedical Analysis, 27 (5), 821-826. https://doi.org/10.1016/s0731-7085(01)00486-1

4. Shaidarova, L. G., Ziganshina, S. A., Tikhonova, L. N., \& Budnikov, G. K. (2003). Electrocatalytic Oxidation and Flow-Injection Determination of Sulfur-Containing Amino Acids at Graphite Electrodes Modified with a Ruthenium Hexacyanoferrate Film. Journal of Analytical Chemistry, 58 (12), 1144-1150. https://doi.org/10.1023/b:janc.0000008953.67244.c2

5. Shpak, A. V., Pirogov, A. V., Shpigun, O. A. (2003). Determination of Amino Acids by Capillary Electrophoresis without Preliminary Derivatization. Zhurnal analiticheskoi khimii, 58 (7), 317-319.

6. Ensafi, A. A., Rezaei, B., \& Nouroozi, S. (2009). Flow injection spectrofluorimetric determination of cystine and cysteine. Journal of the Brazilian Chemical Society, 20 (2), 288-293. https://doi.org/10.1590/s0103-50532009000200013

7. Bhawani, S. A., Mohamad Ibrahim, M. N., Sulaiman, O., Hashim, R., Mohammad, A., \& Hena, S. (2012). Thin-layer chromatography of amino acids: a review. Journal of Liquid Chromatography \& Related Technologies, 35 (11), 1497-1516. https://doi.org/10.1080/10826076.2011.619039

8. Jamalpoor, A., Sparidans, R. W., Pou Casellas, C., Rood, J. J. M., Joshi, M., Masereeuw, R., \& Janssen, M. J. (2018). Quantification of cystine in human renal proximal tubule cells using liquid chromatography-tandem mass spectrometry. Biomedical Chromatography, 32 (8), e4238. https://doi.org/10.1002/bmc.4238

9. Cebi, N., Dogan, C. E., Develioglu, A., Yayla, M. E. A., \& Sagdic, O. (2017). Detection of 1-Cysteine in wheat flour by Raman microspectroscopy combined chemometrics of HCA and PCA. Food Chemistry, 228, 116-124. https://doi.org/10.1016/j.foodchem.2017.01.132

10. European Pharmacopoeia 9.0. (2016). Cystine. Council of Europe: Strasbourg, 2187-2188.

11. Chernobrovkin, M. G., Koltcova, N. V., Shepelev, B. N. (2004). Farmatciia, 5, 18-20.

12. Blazheyevskiy, M. Ye., Riabko, D. N. (2014). Application of peroxy acids as disinfectants and sterilization agents (monograph). Saarbrücken (Deutschland): LAP LAMBERT Academic Publishing. 


\section{Informations about authors:}

Blazheyevskiy M. Ye., Doctor of Chemistry (Dr. habil), professor of the Physical and Colloid Chemistry Department,

National University of Pharmacy, Ukraine. E-mail: blazejowski@ukr.net. ORCID: https://orcid.org/0000-0002-8032-347X

Bondarenko N. Yu., Candidate of Pharmacy (Ph. D), associate professor of the Physical and Colloid Chemistry Department,

National University of Pharmacy, Ukraine. E-mail: tropikana2003@ukr.net. ORCID: https://orcid.org/0000-0003-0620-2255

Serdiukova Yu. Yu., Candidate of Pharmacy (Ph. D), teaching assistant of the Physical and Colloid Chemistry Department,

National University of Pharmacy, Ukraine. E-mail: tamadiw@gmail.com. ORCID: https://orcid.org/0000-0002-4755-3660

Yaremenko V. D., Candidate of Pharmacy (Ph. D), associate professor of the Department of Medicinal Chemistry,

National University of Pharmacy, Ukraine. E-mail: medchem@nuph.edu.ua. ORCID: https://orcid.org/0000-0002-0850-1489

Відомості про авторів:

Блажеєвський М. С., д-р хім. наук, професор кафедри фізичної та колоїдної хімії, Національний фармацевтичний університет,

Україна. E-mail: blazejowski@ukr.net. ORCID: https://orcid.org/0000-0002-8032-347X

Бондаренко Н. Ю., канд. фармац. наук, доцент кафедри фізичної та колоїдної хімії, Національний фармацевтичний університет,

Україна. E-mail: tropikana2003@ukr.net. ORCID: https://orcid.org/0000-0003-0620-2255

Сердюкова Ю. Ю., канд. фармац. наук, асистент кафедри фізичної та колоїдної хімії, Національний фармацевтичний університет,

Україна. E-mail: tamadiw@gmail.com. ORCID: https://orcid.org/0000-0002-4755-3660

Яременко В. Д., канд. фармац. наук, доцент кафедри медичної хімії, Національний фармацевтичний університет, Україна.

E-mail: medchem@nuph.edu.ua. ORCID: https://orcid.org/0000-0002-0850-1489

\section{Сведения об авторах:}

Блажеевский Н. Е., д-р хим. наук, профессор кафедры физической и коллоидной химии, Национальный фармацевтический университет,

Украина. E-mail: blazejowski@ukr.net. ORCID: https://orcid.org/0000-0002-8032-347X

Бондаренко Н. Ю., канд. фармац. наук, доцент кафедры физической и коллоидной химии, Национальный фармацевтический

университет, Украина. E-mail: tropikana2003@ukr.net. ORCID: https://orcid.org/0000-0003-0620-2255

Сердюкова Ю. Ю., канд. фармац. наук, ассистент кафедры физической и коллоидной химии, Национальный фармацевтический университет, Украина. E-mail: tamadiw@gmail.com. ORCID: https://orcid.org/0000-0002-4755-3660

Яременко В. Д., канд. фармац. наук, доцент кафедры медицинской химии, Национальный фармацевтический университет, Харьков, Украина. E-mail: medchem@nuph.edu.ua. ORCID: https://orcid.org/0000-0002-0850-1489 